\title{
Disrupsi dalam Musik
}

\author{
A. Harsawibawa ${ }^{1}$ \\ Universitas Indonesia
}

\begin{abstract}
Disruption in Music. Disruption is identical to chaotic state which is disrupted by the advance of technology especially with its notion of machine replaces men in work. It is said that music as part of men's life are not immune from those chaotic states. Because of its seemingly chaotic state, it is not surprising that no one thought of disruption as having a clear methodology. By adopting a methodology of technical engeneering, this paper has succeded in forming a methodology which is able to explain musical disruption. This methodology has three aspects, i.e.: horizontal aspect which is about the mixing of musical genre with other art genres; vertical aspect which is about the the mixing of subgenres in musical genre; and axiological aspect which is about the interaction between music and non-music disciplines. The method of disruption in music shows that disruption is not a big problem; disruption is something inherent in music. Disruption is something essential in music. It does not pose a real threat to music; it is a condition which enriches the music in its relations to itself, other arts and non-music disciplines.
\end{abstract}

Keywords: music disruption; liberal arts

\begin{abstract}
ABSTRAK
Disrupsi identik dengan keadaan khaos bagi manusia akibat perkembangan teknologi; utamanya gagasan mesin menggantikan manusia. Musik yang merupakan bagian dari kehidupan manusia tidak luput dari khaos yang dihasilkan oleh disrupsi. Karena keadaan khaos itu tidak mengherankan bila banyak orang menduga bahwa disrupsi tidak mungkin memiliki kerangka pikir yang jelas. Tulisan ini, dengan mengadaptasi pemikiran di dalam ilmu teknik berhasil memformulasikan sebuah metodologi untuk memahami disrupsi di dalam musik. Metodologi itu memiliki tiga aspek di dalamnya, yaitu aspek horizontal yang berbicara mengenai percampuran genre musik dengan genre seni lainnya, aspek vertikal yang berbicara mengenai percampuran di dalam genre musik, dan aspek aksiologis yang berbicara mengenai hubungan musik dengan bidang-bidang lain yang bersifat non-musik. Metodologi disrupsi di dalam musik memperlihatkan bahwa disrupsi bukan masalah yang besar; disrupsi merupakan sesuatu yang melekat di dalam musik. Disrupsi adalah sesuatu yang hakiki di dalam musik. Ia tidak mengancam musik, tetapi merupakan sebuah situasi yang memperkaya musik dalam hubungannya dengan dirinya sendiri dan bidang-bidang lain yang bersifat seni maupun nonseni.
\end{abstract}

Kata kunci: disrupsi musik; seni liberal

\section{Pendahuluan}

Menurut artikel Wikipedia dari tahun 2011 yang berjudul "List of Popular Music Genres", jumlah genre di dalam musik populer adalah 348 buah. Bandingkan dengan cara berpikir awam yang sangat pantas untuk diperdebatkan, bahwa genre musik berjumlah empat buah, yaitu: musik klasik dan antonimnya, musik populer, yang di dalamnya terdapat (sub)genre pop, jazz dan rock. Atau, yang lebih teknis lagi menyebutkan adanya 11 genre di dalam musik populer - artinya ada 12 genre musik dengan musik klasik.

Ada contoh perbandingan lain. Artikel Wikipedia dari tahun 2011 yang sama di atas, menyebutkan adanya 83 buah jumlah genre

Alamat korespondensi: Departemen Filsafat, Gedung 7, Fakultas Ilmu Pengetahuan Budaya, Universitas Indonesia. Kampus UI Depok, Jln. Margonda Raya, Depok 16424. E-mail: harsawibawa@yahoo.com; Tlp. +62217867222 . 
musik rock. Tetapi artikel Wikipedia tahun 2018 menyatakan bahwa jumlah genre khusus musik rock saja adalah 249 buah. Secara naif bisa dikatakan bahwa jumlah genre musik rock dalam waktu tujuh tahun meningkat tiga kali lipat.

Jumlah genre atau pun subgenre musik bukanlah masalah utama. Permasalahan itu bisa diperdebatkan, dan penulis bisa membayangkan bahwa perdebatan itu tidak akan ada habishabisnya. Sebab, perdebatan yang ada akan langsung mempersoalkan, mana yang masuk dalam satu genre, mana yang berkategori genre dan mana yang subgenre, dan seterusnya. Singkatnya, akar masalah adalah pada kerangka pikir untuk menentukan kategori genre atau pun subgenre. Proses penciptaan seni dalam kehidupan manusia tidak dapat dilepaskan pada proses penciptaan kemurniaan dan hibriditas yang merupakan unsur yang mendasar (Laksono, Purba, \& Hapsari, 2015). Berkenaan dengan ini para sosiolog berpendapat bahwa selera musik harus bervariasi antar kelompok sosial, tetapi belum mempertimbangkan apakah efeknya melampaui rasa kegunaan musik dan juga reaksi emosional terhadap musik (North $\&$ Davidson, 2013). Tulisan ini lebih melihat pada sisi bagaimana bisa jumlah genre musik "meledak" dari yang tadinya (maksimal) 15 buah - menurut alinea di atas bahkan hanya 12 buah - menjadi 348 buah, atau dari yang tadinya hanya 83 buah menjadi 249 buah. Penulis berkeyakinan bahwa jumlah genre/subgenre musik pada hari ini akan lebih banyak lagi.

Bagaimana bisa jumlah genre/subgenre di dalam musik "meledak"? Apakah itu semua berakar pada hakekat di dalam seni yang berhubungan dengan kreativitas pencipta? Atau, seperti halnya bidangbidang lain dalam kehidupan hari-hari ini, semua itu adalah karena pengaruh teknologi? Ataukah soalnya karena gagasan adalah kebaruan karena konsekwensi perkembangan di dalam seni (avantgardness) dan bahkan kebaruan demi kebaruan itu sendiri (avant-gardism) di dalam seni?

Bahwa seni terus-menerus berkembang karena seniman selalu mencari kebaruan (berhubungan dengan avant-gardness) adalah sebuah konsekuensi logis dari kreativitas seniman. Demikian pula, seniman dengan kreativitasnya mau menciptakan sesuatu sampai pada titik batas yang tak terbayangkan (berhubungan dengan avant-gardism). Salah satu caranya adalah dengan menggunakan teknologi. Tetapi kreativitas tidak cukup untuk menerangkan "ledakan" di dalam genre musik. Akar masalahnya belum terjawab: mengapa terus "memecahkan diri" untuk menghasilkan genre-genre yang berbeda? Mengapa tidak menciptakan saja karya sebanyakbanyaknya dalam genre yang sama?

\section{Disrupsi dalam Bidang Non-Musik}

"Disrupsi" adalah sebuah kata yang menggetarkan dan juga menggentarkan akhir-akhir ini. Seperti yang dikemukakan Suwandana, disrupsi merupakan sebuah situasi yang mengacak-acak pola tatanan lama untuk menciptakan tatanan baru (Suwardana, 2018: 107). Disrupsi ditemukan di dalam dunia bisnis, perbankan, transportasi, sosial masyarakat, hingga pendidikan. Dengan ungkapan yang lebih dalam, Dru mengatakan bahwa disrupsi adalah memecahkan diri dengan status quo; sebuah situasi yang menyangkal kebijaksanaan yang telah ada sebelumnya, untuk mencari penyelesaian masalah secara tak terduga (Dru, 2007: 1).

Jadi, apa itu sesungguhnya yang disebut dengan "disrupsi"? Disrupsi (disruption) berasal dari kata dasar "disrupt" yang berarti "tak teroganisir", "mengganggu", "membolak-balik", "memisahkan", "menyebabkan terpecah”. Dengan kata dasarnya yang dipandang bersifat negatif tersebut, tidak mengherankan bila orang yang tidak siap pada masa ini menganggap disrupsi adalah sebuah situasi yang negatif. Situasi yang dipandang negatif itu, misal hilangnya lapangan kerja karena adanya kemajuan teknologi. Di sini penulis sudah menyebut kata "teknologi"; memang disrupsi pada masa-masa kini yang selalu dihubungkan dengan teknologi.

Mengapa teknologi yang "dipersalahkan", hal ini bukanlah sesuatu yang mengherankan sebab awal mula disrupsi ini memang dihubungkan dengan teknologi. Hal ini semua berakar pada era yang disebut sebagai "Revolusi Industri 4.0". Secara singkat, penulis hanya menyampaikan bahwa revolusi ini terjadi karena kemajuan teknologi baru yang mengintegrasikan dunia fisik, digital dan biologis, yang pada akhirnya mempengaruhi ilmu 
pengetahuan, bidang-bidang ekonomi, industri dan pemerintahan (Rosyadi, 2018). Semua itu karena adanya perubahan paradigma dalam cara bekerja, keahlian, cara mengkonsumsi, cara merancang, manufaktur dan memproduksi (Sulaksono, 2018).

Hal ini terlihat di dalam kasus-kasus disrupsi digital, dimana perusahaan taksi atau ojek tidak perlu memiliki kendaraannya sendiri (Grab, Uber, misalnya), usaha-usaha akomodasi tidak perlu memiliki bangunan sendiri (RedDoorz), perusahaan-perusahaan telekomunikasi tidak perlu lagi memiliki teleco infra (Skype, WeChat), movie house tidak perlu memiliki bioskop (Netflix), vendor-vendor software tidak perlu membuat apps (Apple/ Google), pemilik media populer tidak perlu menciptakan isi (Facebook), dan bank-bank yang tumbuh cepat tidak memiliki uang yang nyata (SocietyOne).

Institusi yang perlu disebutkan sebagai pihak yang paling terkenal imbas disrupsi adalah perguruan tinggi. Institusi ini merupakan pihak yang paling terkena imbasnya secara moral. Hal ini disebabkan karena kedudukannya sebagai lembaga pendidikan dipertanyakan. Pertama, karena sebagian disrupsi disebabkan oleh perguruan tinggi; dan kedua, cara belajar di perguruan tinggi yang harus berubah dalam situasi disrupsi. Untuk menghadapi disrupsi, perguruan tinggi mengubah cara kerja risetnya; misalnya: risetrisetnya menjadi berbentuk kolaborasi antar peneliti dari berbagai disiplin ilmu dan perguruan tinggi. Selain itu, riset yang dilakukan tidak lagi berorientasi pada penyelesaian masalah (problem solving), melainkan dilakukan dalam rangka untuk menemukan potensi masalah maupun potensi nilai ekonomi yang dapat membantu masyarakat untuk mengantisipasi berbagai masalah sosial ekonomi dan politik (Rosyadi, 2018). Selain itu, di dalam bidang pengajaran, fungsi dosen pengajar tidak lagi sebagai pihak yang paling otoritatif; misalnya mahasiswa malah banyak dituntut untuk lebih aktif dalam bentuk diskusi di kelas.

Disrupsi identik dengan teknologi, tidak mengherankan bila disrupsi di dalam musik juga dipandang dalam hubungannya dengan kemajuan teknologi. Sebagian dari pemikiran demikian tidak salah, tetapi penulis akan memperlihatkan bahwa dalam musik, disrupsi tidak sekedar akibat dari teknologi. Oleh sebab itu, yang penting dalam memahami bagaimana disrupsi di dalam musik tidak sekedar akibat dari teknologi, melainkan perlu dipahami apa isi dari disrupsi sehingga ia begitu menggetarkan dan sekaligus menggentarkan itu.

\section{Hakekat Disrupsi}

Disrupsi menunjuk pada gagasan sesuatu yang "pecah", atau lebih tepatnya tindakan yang menyebabkan perpecahan, It (disrupsi) signifies "rupture," or rather the act of "creating a rupture" (Dru, 2007: 1). Sebagai sebuah "tindakan”, disrupsi seharusnya memiliki metodologi yang jelas. Itulah permasalahan di dalam disrupsi yang ditemui pada hari-hari ini; sebagai tindakan yang "memecah" secara tidak sadar disrupsi dipandang juga "sudah pecah" tanpa bisa dianalisis apa tindakannya yang diterima kebanyakan adalah hasil dari adanya dirupsi itu.

Tulisan ini sangat meyakini pemikiran Dru bahwa disrupsi menghasilkan "rupture"; dan rupture itu adalah sesuatu yang positif semata. Di sinilah penulis melihat bahwa untuk menunjukkan disrupsi sebagai sesuatu yang positif dibutuhkan sebuah pemahaman mengenai metodologi disrupsi. Gagasan disrupsi sebagai metodologi dikupas secara gamblang di dalam revolusi industri 4.0 melalui teknologi CPS (Cyber Physical System). CPS adalah teknologi yang mengintegrasikan dunia nyata dan dunia maya (Prasetyo, 2018: 19). Integrasi ini terwujud melalui penyatuan antara proses fisik dan komputasi atau teknologi embedded computers dan jaringan. Kagermann menawarkan sebuah bagan di dalam dunia industri yang mana bagan itu penulis adaptasi untuk memahami disrupsi di dalam musik (Gambar 1).

Gambar 1 memberi inspirasi kepada penulis untuk memahami disrupsi yang tengah terjadi di dalam musik. Bagaimana bisa bagan tersebut menginspirasi, hal ini penulis jelaskan yang merujuk pada hakekat berpikir disruptif di dalam musik. Bagan tersebut memperlihatkan fenomenafenomena di dalam dunia musik sehari-hari yang kelihatannya sama sekali tidak berhubungan dan 
seolah-olah tanpa pola apa pun sehingga sangat sulit untuk dipahami. Dengan adanya bagan tersebut, akan kelihatan bahwa semua fenomena itu sesungguhnya tidak chaos, melainkan memiliki pola yang dapat dipahami dengan kerangka pikir yang tidak biasa. Untuk memperlihatkan bagan di atas beroperasi, di bawah ini penulis akan memaparkan sejumlah kasus di dalam musik.

\section{Aspek Pertama}

Ini adalah integrasi horizontal yang berarti mengintegrasikan teknologi CPS ke dalam strategi bisnis dan jaringan kerjasama perusahaan meliputi rekanan, penyedia, pelanggan, dan pihak lainnya. Integrasi ini adalah proses penyatuan antara sistem dan halhal yang sifatnya tidak sejajar, tetapi menjadi sejajar pada era disrupsi. Kasus disrupsi di dalam musik integrasi horizontal penulis gunakan sebagai kerangka pikir untuk memahami pencampuran antar genre seni, dalam hal ini antara genre musik dan genre seni lainnya. Seperti yang telah disebutkan di atas, aspek pertama yang merupakan integrasi horizontal penulis gunakan sebagai kerangka pikir untuk memahami pencampuran antar genre seni, dalam hal ini antara genre musik dan genre seni lainnya.

Percampuran antar genre seni, dalam hal ini percampuran musik dengan genre seni lain, paling jelas ditemukan di dalam dance music masa kini. Dance music yang ditemukan pada masa kini tidak sama dengan dance music yang terdapat pada masa di dalam sejarah musik, era Barok (1600-1750). Dance music pada masa

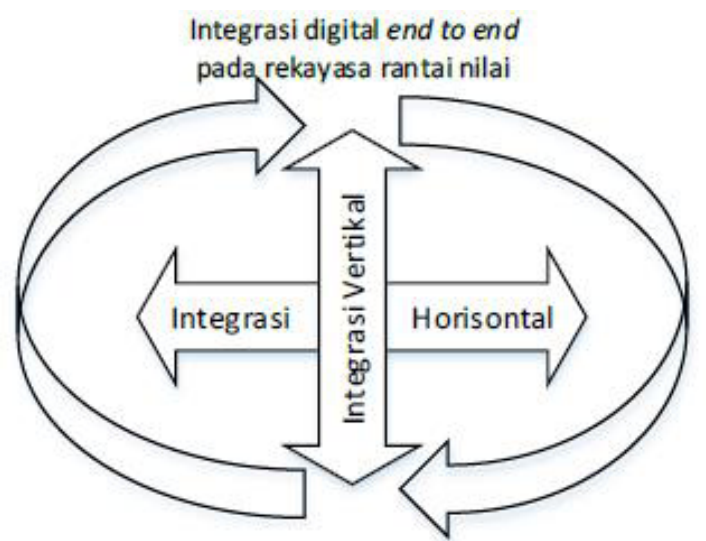

Gambar 1. Tiga Aspek Integrasi Industri 4.0. (Sumber: Kagermann)
Barok adalah musik yang diciptakan dengan diinspirasikan oleh tarian yang ada pada masa itu, sedangkan dance music yang ada pada masa kini diinspirasikan sekaligus mengembangkan tarian yang ada pada masa kini. Semua itu berbentuk musik yang tidak hanya bersifat instrumental, melainkan juga musik vokal.

Dance music bisa ditemukan dengan mudah di saluran-saluran televisi, seperti MTV misalnya. Musik video yang muncul di sana memperlihatkan bahwa musik masa kini tidak cukup hanya didengarkan saja; ada unsur visual yang harus diperhatikan juga di sana. Apa yang visual adalah bagaimana orang atau orangorang yang menggerak-gerakkan tubuhnya sebagai gerakan tarian. Apa yang visual itu tidak cukup disebut tarian semata; sebab, orang juga harus mendengarkan kata-kata yang dinyanyikannya. Itulah sebabnya, seperti yang penulis telah katakan di atas, dance music pada era kontemporer tidak bisa disamakan dengan dance music pada era Barok.

Apa yang terdapat di dalam saluran-saluran televisi itu tidak tiba-tiba muncul. Ada sejarah yang cukup panjang sehingga musik itu demikian adanya. Hal ini mengacu pada dance music di abad ke-20 yang muncul bersama dengan jazz dance, yang berarti juga sekaligus bersamaan dengan perkembangan musik jazz ((Marshall, 1994) \& (Marshall, 1994: xvi)); penulis melihat bahwa perkembangan dance music awal menjadi inspirasi bagi perkembangan dance music atau musik di luar jazz, seperti: rock'n roll (tahun 1950-an), dan selanjutnya disko (tahun 1970an). Bagaimana tarian kemudian berpengaruh terhadap terciptanya genre musik terlihat pada munculnya genre-genre musik yang identik dengan tarian, yaitu: disko, funk, R\&B, hip hop, new wave (yang berasal dari robot dance), house music, techno dan trance.

Sesungguhnya bukan hanya tarian saja yang muncul di dalam musik video, ada juga tindakan-tindakan tertentu yang muncul di dalam menyanyikan atau menggambarkan orang menyanyi. Tindakan-tindakan itu penulis sebut sebagai "akting" di dalam musik. Karyakarya yang bisa penulis sebutkan di mana di 
dalamnya terdapat tindakan akting, yaitu: "Swish Swish" (Katy Perry ft. Nicki Minaj) dimana di dalamnya terdapat dance music dan akting; "Love Me Like You" (Little Mix) dimana di dalamnya terdapat akting; dan "Trouble" (Iggy Azalea ft. Jennifer Hudson) dimana di dalamnya juga terdapat akting (Little \& Jenne, 2001).

Musik video menimbulkan pertanyaan tentunya: apa yang mau disampaikan olehnya? Tentang apa "isi" dari musik video, sudah banyak studi yang bisa ditemukan. Dalam konteks tulisan ini, yang menarik bagi penulis adalah bahwa musik video merupakan sebuah genre yang bercerita tentang genre musik itu sendiri. Maksudnya, lagu telah ada sebelumnya, lalu kemudian sutradara mendesain image dengan lagu itu sebagai pembimbingnya (Vernallis, 2004: x). Ini yang menjelaskan bagaimana sesuatu yang diperlihatkan di dalam musik video itu agak sulit untuk dipahami karena apa yang ada di dalamnya bercerita tentang sebuah image. Jelaslah bahwa akting atau pun tarian di sini menjadi nomor dua; keduanya adalah sekedar sarana, yang terpenting adalah image yang dibangunnya.

Kembali pada permasalahan disrupsi di dalam musik, aspek pertama menunjukkan bagaimana musik memecahkan dirinya dari tradisi sebelumnya. Caranya ternyata karena ada sebuah cara baru untuk memanfaatkan musik. Musik video menunjukkan bagaimana musik menjadi pembimbing di dalam penciptaan sesuatu yang baru - entah itu sekedar berupa karya baru atau pun genre baru, karena di sini yang mau dicari adalah sebuah image.

\section{Aspek Kedua}

Ini adalah integrasi vertikal yaitu menerapkan teknologi CPS ke dalam sistem manufaktur/produksi yang ada di perusahaan. Integrasi ini adalah proses penyatuan antar sistem yang sejajar. Walaupun sistem-sistem itu sejajar, tetapi pada era sebelum adanya disrupsi sistem-sistem itu dipandang sebagai sistemsistem yang otonom dan bersifat independen satu sama lain. Kasus disrupsi di dalam musik integrasi vertikal penulis gunakan sebagai kerangka pikir untuk memahami pencampuran (subgenre) di dalam genre musik.

Seperti yang sudah disampaikan, integrasi vertikal penulis gunakan sebagai kerangka pikir untuk memahami pencampuran (sub genre) di dalam genre musik. Permasalahan ini memiliki akar sejak munculnya gagasan postmodern "tiada lagi perbedaan antara 'budaya tinggi' dan "budaya rendah'". Kejadian ini terlihat secara nyata di dalam musik populer. Oleh sebab itu, aspek kedua dimulai dari sejarah mutakhir musik populer.

Sejarah ini ditandai oleh suatu kecenderungan ke arah percampuran genre dan aliran musik secara sengaja. Seperti yang dikatan Hsu bahwa musik populer selalu omnivora budaya (Hsu, 2017). Percampuran ini dilakukan dalam bentuk mengolah musik yang sudah ada dari masa lalu, sampai dengan melakukan eksperimentasi musik, bunyi dan alat-alat musik yang berbeda dalam rangka menciptakan identitas baru. Contoh: pencampuran antara genre musik rock dan genre musik pop; penggunaan perpaduan dan konstruksi mirip kolase dari genre-genre reggae, rap dan hip hop. Selain itu munculnya kembali bentuk-bentuk dance music - yang dulunya disko, sekarang house music, misalnya. Jadi yang menarik dari musik rock, misalnya, adalah bukan karena genre ini meminjam genre-genre musik musik yang ada; melainkan karena genre ini menggunakan sejumlah genre yang ada untuk membuat sesuatu yang sama sekali baru. Semua itu adalah sebuah gejala dari postmodernisme di dalam musik. Idiom-idiom postmodernis yang ditemukan di dalam musik adalah: Pastiche, Camp, Kolase, Skizofrenia, dan Parodi.

\section{a. Pastiche}

Pastiche adalah idiom di dalam postmodern yang menunjukkan kesukaan pada membangun karya berdasarkan karya-karya yang telah ada. Dasarnya tetap: (a) eklektis (yang paling utama), (b) penekanan pada "gaya", bukan "isi", dan (c) Tidak ada perbedaan antara budaya elit dan populer (tidak ada: musik klasik vs. musik non-klasik). 


\section{b. Camp}

Nicki Minaj adalah contoh dari camp. Pertunjukan dan penampilan Minaj memperlihatkan karakternya yang kuat serta menegaskan otonomi di dalam industri musik yang patriarkal; pertunjukan dan penampilannya menantang politik rasial dan gender, selain juga "mengusik" male gaze. Dengan cara itu, Minaj membebaskan dan membongkar gagasan moralitas dan normativitas seksual orang AfricanAmerican.

\section{c. Kolase}

Asal-usulnya dari teknik di dalam produksi seni rupa, di mana karya dibangun dari sejumlah hasil tempelan potongan-potongan karya untuk membangun sebuah karya yang sama sekali baru. Di dalam musik, kolase dihasilkan dari kemajuan pesat di dalam teknologi rekaman. Ada dua jenis kolase di dalam musik, yaitu Bootleg dan "Montase".

\section{d. Skizofrenia}

Idiom skizofrenia berbentuk peminjaman atau mengambil inspirasi dari musik masa lalu, untuk menghasilkan musik yang (seolah-olah) baru. Istilah kasarnya adalah "musik 'daur ulang".

\section{e. Parodi}

Penekanan parodi adalah pada penyimpangan atau "plesetan" atas gaya/ karya yang ada. Apa yang diparodikan adalah kelemahan, kekurangan, keseriusan, atau bahkan kemasyuran karya.

Apa tujuan paparan idiom di atas? Paparan itu ingin menunjukkan kemunculan genre musik yang (seolah-olah) baru karena ada-nya percampuran genre-genre besar. Percampuran itu dimungkinkan karena penggunaan idiom-idiom postmodernisme di dalam musik. Jadi, idiom-idiom itu berguna untuk merekatkan atau menyatukan genre yang berbeda atau bahkan genre yang sama untuk dikesankan menghasilkan genre baru.

\section{Aspek Ketiga}

Integrasi ini adalah proses penyatuan secara aksiologis. Di sini terjadi penerapan teknologi
CPS ke dalam rantai rekayasa nilai secara end to end. Rantai rekayasa nilai menyangkut proses penambahan nilai dari produk. Di dalam proses ini sesuatu yang tadinya dipandang "bebas nilai" menjadi bermasalah dalam konteks kemunculan sesuatu itu. Kasus disrupsi di dalam musik, aspek ketiga ini menjelaskan bahwa permasalahan musik sekarang tidak hanya dalam permasalahan yang bersifat teknis musik semata atau pun musik teori, melainkan sudah masuk dalam bidang-bidang lain non-musik yang mengakibatkan musik dapat dipandang sebagai sebuah bidang studi yang interdisipliner. Aspek ketiga menjelaskan bagaimana musik berhubungan dengan bidang hukum, manajemen, teori-teori biologi, fisika, dan lain sebagainya. Aspek ketiga menjelaskan bahwa permasalahan musik sekarang tidak hanya dalam permasalahan yang bersifat teknis musik semata atau pun musik teori, melainkan sudah masuk dalam bidang-bidang lain nonmusik yang mengakibatkan musik dapat dipandang sebagai sebuah bidang studi yang interdisipliner.

Aspek ketiga adalah aspek yang paling luas di dalam disrupsi di dalam musik. Aspek ini memang dibangun dari adanya kemajuan teknologi. Tetapi dalam aspek ini, teknologi sudah diterima begitu saja sebagai "conditio sine qua non”. Dalam sejumlah kasus, karena aspek teknologi ini pula, maka paling mudah menghubungkan disrupsi dengan aspek ini ketika orang bicara mengenai disrupsi di dalam musik, aspek ini pastilah yang ditunjuk. Aspek ini banyak menunjukkan disrupsi musik dalam genre musik populer. Memang tidak salah; tetapi tidak lengkap. Sebab, pengaruh disrupsi musik hanya sebagian saja dari wilayah musik. Lebih-lebih, pengaruh itu bersifat musik praktis; padahal tulisan ini mau menunjukkan bagaimana disrupsi musik berpengaruh ke segala bidang di dalam musik.

Untuk mendapatkan pemahaman yang utuh, penulis membagi permasalahan di dalam aspek aksiologis menjadi tiga bagian: a) dunia musik populer; b) bidang ilmu lain masuk; dan c) analisis dalam musik. 


\section{a. Dunia Musik Populer}

Di dalam dunia musik populer, perubahan adalah segi yang tetap; dan perubahan itu hampir selalu disebabkan karena teknologi (Hughes, Evans, Morrow, \& Keith, 2016: 2). Yang berbeda sekarang ini adalah kecepatan dan juga konsekuensi dari perubahan itu. Perubahan menjadi cara bagaimana musik diproduksi (misal: studio, rumahan, atau venue), didistribusikan (misal: penjualan fisik, online platforms) dan dikonsumsi (misal: secara digital). Perubahan itu terjadi karena adanya digital aggregator, konsultan media sosial dan situs online streaming (Hughes et al., 2016: 2). Salahsatu hal penting dalam ekosistem musik adalah transmisi, hal ini dipaparkan oleh Irawati dalam kasus musik Kelentangan pada masyarakat Dayak Benuaq bahwa aspek-aspek dalam transmisi musik meliputi konten, pelaku, dan mekanisme (Irawati, 2017).

Perubahan yang mendasar terjadi di dalam bisnis musik; cara bagaimana masuk ke dalam bisnis itu, ukuran sukses (Hughes et al., 2016: 3). Kita bisa mengatakan bahwa terjadi perubahan sistem nilai di dalam dunia ini. Contoh pertama: Reid menyebutkan bahwa pada paruh kedua tahun 2015, pembajakan musik meningkat $16,5 \%$ dan 576 situs yang memproduksi musik bajakan dikunjungi lebih dari 2 milyar kali. Data-data ini mengatakan bahwa dibutuhkan peran pemerintah dan regulator yang memaksa munculnya solusi baru atas masalah ini. Apakah permasalahan pembajakan yang mengganggu produksi karya? tidak juga. Hal ini terlihat dari contoh kedua di bawah.

Contoh kedua adalah walaupun sudah ada perlindungan yang mencukupi, band Atoms for Peace menarik musik mereka dari situs streaming Spotify. Penarikan itu memiliki alasan karena Spotify dan situs streaming tidak membantu dalam mengembangkan musik yang baru. Ini juga terjadi pada Taylor Swift pada tahun 2014. Swift beralasan bahwa penarikan itu berhubungan dengan permasalahan artistik.
Penulis menyebut hal seperti contohcontoh tadi sebagai perubahan sistem nilai, di sini yang pertama adalah dari sisi seniman. Seniman harus menemukan cara baru untuk berinteraksi dengan audiens, menghasilkan contents, berhadapan dengan figur-figur di dalam dunia industri. Istilah yang tepat untuk situasi seniman masa kini adalah "the age of artist-entrepreneurship" (Hughes et al., 2016: 6). Kedua, dari sisi pemerintah dan regulator. Permasalahan bisnis yang baru misalnya adalah hilangnya pajak penjualan atau pajak impor. Selain itu, produksi dan distribusi digital membuat rumit usaha untuk meningkatkan kuota local content dan juga usaha perlindungan untuk industri dan seniman lokal karena tidak ada batas yang mutlak di internet. Pemerintah bisa saja membuat aturan-aturan yang membatasi $\mathrm{di}$ suatu negara, tetapi secara praktis tidak ada batasan bagi seniman kecil di suatu daerah untuk mendunia.

Sarana untuk menghasilkan penemuan di dalam musikpun mengalami perubahan. Selama puluhan tahun, radio dan televisi menjadi alat untuk menghasilkan lagulagu "hits". Memang sarana-sarana itu masih digunakan hingga kini, tetapi sudah tidak menjadi yang utama. Sebagai contoh, "bintang" dapat muncul dari online channel. Perubahan menjadi sangat konstan sejak internet mewabah pada pertengahan tahun 1990-an (Hughes et al., 2016: vi). Pada saat ini hampir semua alat-alat digital memiliki perangkat rekam dan video editing, akibatnya adalah hampir semua orang bisa menciptakan bunyi dan gambar-gambar visual sesuka mereka. Para pembuat musik masa kini harus berhadapan dengan "orangorang awam" ini; akibatnya mereka harus menciptakan sesuatu yang sangat menonjol, yang orang belum pernah lihat atau dengar (Hughes et al., 2016: vii).

Pada masa kini, seniman menyebarkan karya mereka ke konsumen melalui music online. Jika dulu langkah pertama adalah seniman mendatangi label rekaman, maka 
sekarang langkah pertama adalah seniman ke konsumen. Peran label saat ini bukan menentukan "pemenang" (seniman yang pantas untuk "disebarluaskan"); peran label sekarang adalah untuk mengamplifikasi "likes" dari audiens. Ini semua menunjukkan bagaimana "disintermediation" memaksa perubahan (Hughes et al., 2016: x), di sini terjadi perubahan proses penyebaran musik secara radikal.

\section{b. Bidang Ilmu Lain}

Segala sesuatu dapat tampil di dalam musik karena teknologi. Cara untuk tampil itu adalah dengan rekayasa teknologi, entah itu teknologi secara visual maupun teknologi bunyi. Penulis akan menunjukkan hasil teknologi dalam merekayasa tampilan maupun bunyi tersebut.

Pertama, penulis akan menunjukkan rekayasa tampilan. Dengan teknologi, music video bisa melebihi tidak hanya dalam bentuk permainan visual-effect bagi penyanyi yang tampil di dalamnya; teknologi memungkinkan music video bercerita mengenai suatu hal yang berhubungan dengan bidang ilmu tertentu. Contoh hasil permainan teknologi visual yang berhubungan bidang ilmu lain, dalam hal ini optika, adalah lagu "Go Up".

"Go Up" adalah sebuah music video yang dihasilkan dengan cara menyatukan dua adegan yang terpisah untuk menghasilkan gambar yang koheren. Tindakan penyatuan itu diperkuat oleh lirik "Everybody close your eyes, ascend and go up" - yang seolaholah memerintahkan audiens untuk "naik tingkat" dalam menghadapi visual yang ada. Apa yang dilakukan oleh music video itu adalah sebuah tindakan menghasilkan ilusi visual atau ilusi optikal. Cara melakukannya adalah dengan mempermainkan "figureground organization" - pemahamannya didapat dari psikologi Gestalt. Mungkin di dalam musik, apa yang dilakukan oleh Cassius adalah suatu hal yang baru. Tetapi di dalam seni rupa, sudah banyak seniman yang melakukan ilusi visual tersebut; yang paling terkemuka adalah M.C. Escher dan Salvador Dali. Persoalan inilah yang terjadi dalam music video, apakah kita sekedar mendengarkan saja, ataukah cukup melihat saja? atau, apakah musik menjadi semacam bunyi-bunyian yang sifatnya hipnosis?

Kedua, rekayasa bunyi, contohnya adalah penggunaan teknologi rekaman di dalam "Café 1930" yang dimainkan oleh duo trompet-gitar, Alison Balsom dan Miloš Karadaglić. Untuk melakukan perekaman karya ini, pastilah tidak diperlukan teknologi perekaman yang canggih, tetapi yang dibutuhkan adalah suasana yang dapat menimbulkan "kekacauan". Trompet dan gitar adalah dua instrumen musik yang sangat sulit untuk "disatukan" di dalam tampilan akustik murni. Alasannya, suara trompet terlalu keras untuk gitar; jika dimainkan secara akustik murni, pastilah suara gitar akan "tenggelam" oleh trompet, tetapi dengan rekayasa teknologi rekaman gitar dan trompet dapat dipersatukan.

\section{c. Analisis dalam Musik}

Disrupsi tidak hanya terjadi di dalam praktek musik karena disrupsi juga terjadi di dalam pemahaman mengenai musik secara teoretis. Untuk mendapatkan pemahaman yang utuh atas masalah ini, penulis akan mulai dari musikologi. Memahami permasalahan musik yang bersifat interdisipliner dengan bidang ilmu lain dapat ditelaah melalui apa yang dipelajari oleh musikologi yaitu. Akustik: bidang-bidang di dalamnya menelaah permasalahannya dibantu/ bekerja sama dengan bidang ilmu fisika, matematika, arsitektur dan psikologi; Fisiologi: anatomi tubuh dan fisiologi; Psikologi musik: psikologi umum; Pedagogi musik: pedagogi; dan Musikologi perbandingan: antropologi (dan percabangannya).

Keadaan disruptif di dalam musik yang paling sulit untuk dipahami adalah di dalam permasalahan analisis. Sudut pandang material analisis mungkin tidak terlalu revolusioner; yang revolusioner adalah dalam hal sudut pandang formalnya. Penulis 
membagi permasalahan besar sudut pandang formal itu ke dalam dua hal, yaitu.

1. Analisis lirik

Pada awalnya, musik populer dipandang sebagai musik yang "berkasta rendah", dibandingkan dengan musik serius. Kesalahpahaman itu berangkat dari penyamaan cara menganalisis antara musik serius dan musik populer. Salah satu hal yang membuat musik populer akhirnya menjadi sejajar dengan musik serius adalah karena permasalahan analisis liriknya.

Studi mengenai lirik di dalam musik populer tentang permasalahan analisis lirik secara umum, penulis mengacu pada Middleton (2000) dan Machin (2010). Sedangkan untuk paparan yang paling komprehensif dalam berbicara mengenai tema lirik, penulis mengacu pada Cooper (1991). Referensi tersebut menunjukkan bagaimana musik populer berhubungan dengan studi sastra; studi ini mirip dengan studi mengenai puisi. Lirik di dalam musik populer ternyata memiliki nilai yang penting dalam mempotret situasi sosial masyarakat. Tidak heranlah bila lirik menjadi salah satu bagian yang penting di dalam studi musik.

2. Analisis visual

Walaupun studi mengenai perwajahan cover album banyak membicarakan album-album musik populer, tetapi sesungguhnya studi ini tidak terbatas pada musik populer. Machin (2010: 65) menunjukkan bagaimana cover album musik serius juga bisa ditelaah; sayangnya memang telaah tersebut masih harus memperbandingkannya dengan musik populer.

Analisis atas cover album menjadi penting karena cover album yang dibuat oleh sebuah grup musik secara tidak langsung memotret keadaan psikologis grup tersebut, selain yang lebih penting lagi adalah dari genre apa grup tersebut, serta perkiraan isi album grup tersebut.
Studi mengenai perwajahan cover album menunjukkan secara jelas sifat interdisipliner studi musik masa kini. Untuk memahami grup musik dan lagulagu di dalamnya, cover album itu harus dibaca menggunakan psikologi warna, psikologi sosial dan bahasa tubuh.

\section{“Inspirasi Separatisme” untuk Musik}

Mengapa disrupsi di dalam musik sedemikian parahnya? Apakah ini disebabkan oleh teknologi - seperti halnya bidang-bidang lain di luar musik? Menurut penulis, teknologi memang berperan di dalam disrupsi di dalam musik, tetapi itu bukan masalah utamanya. Penulis berpendapat bahwa disrupsi sudah melekat di dalam diri musik; dan hal itu terpahami dengan melihat pada sejarah perkembangan gagasan musik.

Banyak pendapat tentang asal-usul musik sebagai sebuah ilmu pengetahuan yang berhubungan dengan praktek musik dimulai pada Abad Pertengahan dengan adanya musik sebagai bagian dari Quadrivium di dalam Liberal Arts. Untuk memahami apa itu musik dan bagaimana kedudukannya di dalam Quadrivium/LiberalArts, di bawah ini penulis akan memaparkan Liberal Arts secara global dan bagaimana kedudukan musik di dalamnya.

Liberal Arts atau Artes Liberales adalah sebuah sistem pendidikan yang menjadi ciri di Abad Pertengahan. Tujuan dari pendidikan ini adalah mengembangkan kemampuan kognitif. Di dalamnya terdapat trivium (terdiri dari bidangbidang studi: gramatika, retorika dan dialektika) dan quadrivium (terdiri dari bidang-bidang studi: geometri, aritmetika, astronomi, dan musik). Daftar Liberal Arts yang terdiri dari tujuh bidang dibangun pada abad I SM. Tetapi awal dari pembagian itu telah ditemukan pada masa-masa sebelumnya, yaitu pada masa Yunani Kuno; semua itu berakar dari pemikiran Pitagoras dan Archytas dari Tarentum. Di katakan bahwa Pitagoras adalah orang pertama yang menggunakan istilah "kosmos" (kosmos) untuk menunjuk pada "kesatuan dari keseluruhan" (the sum of the whole) sebagai dunia yang tertata, indah dan harmonis. Keseluruhan 
alam semesta dimodelkan berdasarkan bilangan, dan angkasa luar ditata berdasarkan korelasi yang harmonis dari hubungan matematis (Stamatellos, 2012: 37). Setelah Pitagoras dan Archytas, bidang bahasa dikembangkan oleh Isokrates dan bidang matematisnya oleh Plato. Setelah masa Yunani Kuno, pada budaya Helenis dan era Abad Pertengahan, Liberal Arts dibicarakan secara mendalam oleh Agustinus; selain itu, Boethius banyak menulis mengenai bidang aritmatika, astronomi dan musik. Di kemudian hari, pada masa itu pula, Liberal Arts dibicarakan kembali oleh Martianus Capella dan Isidorus dari Sevilla.

Liberal Arts pada masa Yunani Kuno dan Abad Pertengahan harus dipahami dalam hubungannya dengan latar belakang tiga wilayah kognitif yang diarahkan oleh nalar (reason), yaitu bidang teoretis, praktis dan puitis - sesuatu yang merupakan "productive action". Productive action (Yunani: technê) itu adalah suatu tindakan yang diarahkan oleh nalar dalam rangka memproduksi sesuatu yang baru, yang biasanya bersifat instrumental bagi manusia demi mendapatkan hidup yang bernilai. Ini adalah suatu "dikotomi" yang bersifat Platonian. Di satu sisi manusia harus bertindak melalui tubuhnya yang fisik; di sisi yang lain, ia bertindak dalam mengejar sesuatu yang bersifat rohaniah: hidup yang bernilai. Dengan demikian, LiberalArts di Abad Pertengahan adalah sebuah usaha untuk menerjemahkan gagasan Platonian tersebut; di sini tugas Liberal Arts adalah mengarahkan manusia pada dunia Idea (Johnson \& Stahl, 1971: 90-91).

Pada masa itu, istilah "art" memiliki jangkauan semantis yang lebih luas daripada sekarang; yang disebut art pada masa itu termasuk di dalamnya adalah fine art, industry, kemampuan bertukang (craftmanship), ketrampilan capaian (acquired skill) dan ilmu pengetahuan (the sciences). Jelaslah bahwa pada masa itu yang disebut art mencakup semua "ketrampilan menghasilkan" (skill in production). Alasannya, segala sesuatu dapat ditransformasikan dari satu bentuk ke bentuk lainnya, dan juga diarahkan pada suatu tujuan.

Dasar dari Liberal Arts adalah pemahaman bahwa setiap art di dalamnya merupakan kemampuan untuk menghasilkan sesuatu dengan mengikuti arahan nalar. Unsur pengarahan oleh nalar ini sangat penting, sebab di dalamnya mencakup pengacuan pada dunia dengan mencari justifikasi berdasarkan suatu hal dan mengikuti aturan yang objektif, yang berasal dari hal itu sendiri. Dengan demikian art mencakup "melengkapi alam", "meniru alam" dan "menghasilkan sesuatu yang baru di dalam alam".

Justifikasi bagi trivium, tiga studi yang pertama dari Liberal Arts, sederhana saja (Johnson \& Stahl, 1971: 91). Pertama, gramatika (grammarl tata bahasa) berhubungan dengan unsur bahasa dan studi sastra. Pentingnya bidang ini adalah memperkenalkan budaya warisan suatu bangsa artinya merupakan dasar dari semua pendidikan. Kedua, dialektika (dialectic) merupakan pelatihan logika - pelatihan formal dalam hal berpikir verbal. Ketiga, retorika (rhetoric) adalah pelatihan ekspresi.

Quadrivium adalah genus dengan spesiesspesiesnya aritmetika, geometri, astronomi, dan musik. Yang mempersatukan keempat spesies itu adalah karena masing-masing berhubungan dengan "bilangan" (number), atau tepatnya "magnitudo" (magnitude) (Johnson, 1971: 92). Menurut Boethius, alam semesta dipersatukan oleh magnitudo. Aritmatika berhubungan dengan magnitudo itu sendiri, geometri: magnitudo yang tak bergerak, astronomi: magnitudo yang bergerak, musik: hubungan antar magnitudo. Menurut Boethius lebih lanjut, para filsuf mempelajari keempat bidang itu adalah karena segala sesuatu di dalam alam dibentuk dari dasar bilangan. Aritmetika sebagai ilmu bilangan adalah kunci dari bidang-bidang yang lain; geometri: studi mengenai bilangan yang memiliki bentuk (shape), astronomi: bentuk yang bergerak, dan musik: disiplin bilangan dalam proporsi-proporsinya. Karena yang terakhir itulah tidak mengherankan bila musik dipandang sebagai kunci dalam semua hubungan di dunia ini: badaniah dan rohaniah, kuantitatif dan kualitatif.

Jelaslah bahwa quadrivium memiliki tujuan untuk menguak tidak hanya dunia fisik, melainkan juga dunia ilahiah, serta jiwa manusia. Di sini quadrivium memiliki dua tujuan yaitu pertama, melatih pikiran dalam konsep dan skill matematis; sesuatu yang dibutuhkan dalam usaha memahami dan menyelidiki pendasaran dunia yang bersifat matematis. Kedua, memurnikan jiwa dalam 
usahanya mengarahkan manusia pada hal-hal yang imaterial dan abstrak (Johnson \& Stahl, 1971: 93).

Inilah yang mulai menjelaskan mengapa musik berkedudukan di dalam Liberal Arts. Musik, atau sesungguhnya lebih tepat untuk disebut dalam bahasa aslinya yaitu musica, memiliki peran penting dalam mengetahui, menulis dan penciptaan tatanan dunia yang diskursif (Hicks, 2017: 68); musica abad ke-12 adalah Liberal Arts yang mencakup musikologi yang sifatnya matematis dan ilmu pengetahuan alam yang sifatnya metafisik. Walaupun masih menjadi bahan perdebatan, perlu dicatat juga bahwa sejumlah ahli menyebutkan adanya pembagian yang lain, yaitu Hicks (2017: 69): musica activa (sisi praktis dari pengetahuan musik) dan musica speculativa (sisi teoretis dari pengetahuan musik).

Musik merupakan kunci dalam semua hubungan di dunia ini: badaniah dan rohaniah, kuantitatif dan kualitatif. Kemudian, dikatakan bahwa musik memiliki peran penting dalam mengetahui, menulis dan penciptaan tatanan dunia yang diskursif - artinya musik merupakan kunci dalam semua hubungan di dunia ini: badaniah dan rohaniah, kuantitatif dan kualitatif. Pernyataan-pernyataan itu tentunya menimbulkan kebingungan: apakah musik sedemikian luar biasanya sehingga ia dipandang sebagai sesuatu yang mencakup hampir semua hal? Pertanyaan yang mengarah pada sesuatu yang bersifat kualitatif itu bisa diarahkan pada pertanyaan yang sederhana tetapi masuk pada hakekat musik: apakah yang dimaksud dengan musik pada masa itu, sehingga ia bisa memiliki kemampuan untuk mencakup hampir semua hal?

Perkembangan pembelajaran musik di Latin Barat dibangun dari apa yang oleh orang Yunani Kuno disebut "musica" atau "harmonica". Musica ini tidak sama dengan "musik" atau pun "teori musik" seperti yang dikenal sekarang. Musica di awal Abad Pertengahan, di satu sisi, tidak dapat dipisahkan dari pendidikan secara umum; tetapi di sisi yang lain, musica juga tidak dapat dipisahkan dari lagulagu liturgis (liturgical chant) yang berkembang saat itu (Bower, 2002: 136). Ini menjadi pemahaman awal bahwa musica tidak sama dengan musik; atau lebih tepatnya: musica hanya sebagian saja berarti sama dengan musik yang kita kenal sekarang.
Musica sudah ada sebelum Abad Pertengahan; ia muncul pertama kalinya sebagai pendidikan dasar bagi calon orator di Romawi Kuno. Bidangbidang studi di dalamnya (artes) dipandang hakiki dalam pelatihan orang-orang yang bukan budak dan tidak lagi memiliki kewajiban untuk bekerja (homo liber). Itulah sebabnya, di kemudian hari bidang-bidang studi itu disebut sebagai Artes liberales (Liberal Arts). Marcus Terentius Varro, di dalam karya besarnya, Nine Books on the Disciplines (Disciplinarum libri IX), menawarkan sembilan bidang studi yang dipandang penting bagi "orang bebas", yaitu: gramatika, dialektika, retorika, geometri, aritmetika, astrologi, musik, kedokteran an arsitektur (Bower, 2002: 137). Mengapa musica menjadi pendidikan dasar bagi orator, hal ini disebabkan karena musica memberi sejumlah fakta dan referensi yang diperlukan di dalam wicara. Dengan demikian, saat berorasi nantinya sang orator memiliki banyak materi untuk mempesona audiens (Bower, 2002: 137).

Para ahli berbeda-beda dalam memandang artes mana yang pantas masuk ke dalam musica. Tetapi mereka sama dalam memandang musik sebagai bagian yang tak terpisahkan dari musica. Tokoh yang menjadikan Liberal Arts berjumlah tujuh buah, dan bahkan menjadikan artes-artes itu kanonikal di Abad Pertengahan adalah Martianus Capella. Ia juga mentransformasi tradisi artes retorika Romawi sebagai alat untuk mengangkat pikiran manusia ke tingkatan intelek ilahi (Bower, 2002: 139). Apa yang dilakukannya merupakan resonansi gagasan Platonis mengenai bidangbidang studi manusia sebagai alat menuju dunia Idea. Pemikiran Martianus diperdalam oleh para cendekiawan Kuno dan Abad Pertengahan dari tradisi Platonis: rasio yang mengatur tatanan tertinggi dari alam semesta dan dunia metafisik berbentuk keselarasan musikal atau musical concord (Bower, 2002: 140).

Boethius ( 480 - 525/26) adalah cendekiawan yang paling berpengaruh dalam tradisi Platonis di Abad Pertengahan. Ia kurang tertarik pada trivium (Bower, 2002: 142); ia mendefinisikan program pendidikan dalam kerangka studi matematis sesuatu yang akan mempengaruhi studi musica selama lebih dari 1.000 tahun. Mengikuti kaum 
Pitagorean dan pengarang Platonis sebelumnya, Boethius membagi kuantitas menjadi dua genera, yaitu discrete quantity (multitudo) dan continuous quantity (magnitudo). Dua genera kuantitas yang mendasar itu dibagi lagi menjadi dua spesies, yaitu sebagai berikut.

1. Multitudo yang direpresentasikan oleh bilangan, dimana setiap bilangan itu (a) dipandang dalam dirinya begitu saja (sebagai ganjil, genap, prima, dst.) dan (b) dipandang berhubungan dalam hubungannya dengan bilangan lainnya (dalam rasio dan proporsi)

2. Magnitudo yang direpresentasikan oleh bentuk (shapes), dimana setiap bentuk itu (a) dipandang tetap dan tak tergerakkan (contoh: garis, segitiga, kubus, dst.) dan (b) dipandang bergerak (contoh: matahari, bulan, bintang, dst.)

Pembahasan mengenai kuantitas itulah terbentuk empat bidang studi, yaitu: aritmatika yaitu studi mengenai bilangan itu sendiri atau bilangan in and of itself; musik atau studi mengenai bilangan di dalam rasio dan proporsi; geometri atau studi mengenai magnitudo yang tak tergerakkan; dan astronomi atau studi mengenai magnitudo yang bergerak. Boethius menyebut keempat bidang studi itu sebagai “quadrivium”, empat jalan yang menjauhkan jiwa dari perbudakan pengetahuan inderawi menuju pada penguasaan/pemahaman atas esensi-esensi yang tak tergerakkan. Hal inilah yang menjelaskan mengapa musica menjadi prasyarat bagi studi filsafat (Bower, 2002).

Berdasarkan pemaparan tersebut, musik adalah bidang studi yang paling unik dan menarik. Sebab, musik adalah bidang studi yang paling inderawi; jadi, ia dapat mempengaruhi tingkah laku dan bahkan membentuk karakter. Tetapi orang yang rasional harus mengolah musik menurut prinsipprinsip yang sifatnya rasional; prinsip-prinsip itu mencerminkan esensi yang paling konsonan yang ditemukan di dalam spesies kuantitas di dalam rasio dan proporsi yang indah. Setelah berbicara mengenai esensi matematis, Boethius membagi musik dalam tiga kategori, yaitu Musica mundana atau cosmic music; Musica humana atau buman music; dan Musica in instrumentis constituta atau instrumental music (Bower, 2002:
146). Ketiga kategori itu dielaborasi menjadi tiga pembagian yang berhubungan dengan penyebutan "musisi", yaitu instrumentalis (performer), penyair (komponis) dan "hakim" yang menentukan siapa performer dan siapa komponis (Bower, 2002: 146). Menurut Boethius, hanya yang ketiga itulah yang pantas disebut sebagai musisi yang sesungguhnya (true musician). Sebab yang ketiga itu, melalui nalarnya, berhubungan dengan permasalahan mengetahui esensi mendasar yang menentukan nilai performance dan komposisi yang dalam terminologi sekarang, yang ketiga itu disebut sebagai "teoretisi (musik)" (ahli musik/ ilmuwan musik/ musikolog).

Pembagian musik dan musisi di atas menghubungkan Boethius dengan pemikiran musik tradisi Platonis: esensi yang diekspresikan di dalam rasio melampaui semua tingkat keberadaan (level of being). Hanya dengan mengetahui esensi bahkan esensi yang terdapat di dalam dunia bunyi yang badaniah - itulah pikiran dapat mengatasi pengalaman inderawi yang terbatas dan naik tingkat dalam hal mengetahui. Tujuan mempelajari musica adalah "naik kelas" ke tingkat nalar, nilai (value) yang menjadi arah musicus merupakan prinsip-prinsip a priori yang mendasari cara berpikir abstrak; jadi bukan prinsip yang ditemukan di dalam musik aktual (Bower, 2002: 147). Sistem diatonis - yang berhubungan dengan rasio - yang dibicarakan oleh Boethius sedikit sekali, atau bahkan tidak sama sekali, berhubungan dengan karya-karya musik. Nama-nama nada dan tetrakor memang memiliki hubungan dengan nama-nama nada dan tetrakor yang aktual, tetapi di dalam tradisi teoretis Abad Pertengahan, nama-nama dan tetrakor itu hanya ada sebagai konstruk (construct) bagi entitas abstrak yang dibangun oleh prinsip-prinsip aritmetika (Bower, 2002).

Pemikiran Boethius dilanjutkan oleh Aurelian dan Regino. Aurelian memperkenalkan pembedaan antara musicus dan cantor (Bower, 2002: 152). Mengikuti Boethius, musicus adalah musisi yang sesungguhnya; musicus adalah orang yang memahami musik sebagai disiplin yang spekulatif. Sementara itu cantor hanya sekedar menerapkan skill yang sifatnya praktis. Pemikiran mengenai perbedaan antara musicus dan cantor menunjukkan bagaimana pemikiran yang bersifat filosofis di 
dalam musica menyatu dengan praktek-praktek musik dan hal ini ditemukan di gereja-gereja abad ke-9.

Sementara itu Regino mengacu pada pemikiran Platonis yang terdapat pada musica awal. Dengan orisinalitasnya yang sesuai dengan praktek dan semangat biara-biara abad ke-9, ia menawarkan ontologi musik yang merasionalisasikan studi sistematis atas chant dan disiplin musica kuno (Bower, 2002: 152). Natural music (musica naturalis) adalah musik yang dinyanyikan oleh manusia dalam rangka puji-pujian kepada Tuhan. Sementara artificial music (musica artificialis) adalah musik yang dimainkan oleh alat-alat buatan manusia, yaitu instrumen musik.

Di samping "hiruk-pikuk" Liberal Arts dan musik di dalamnya, di Abad Pertengahan juga muncul traktat Musica enchiriadis yang berbeda semangatnya. Traktat ini bersifat eklektis Yunani Kuno-Romawi Kuno. Walaupun demikian, pemikiran di dalamnya berakar secara mendalam dan dibangun dari praktek musik liturgi Roma, selain itu, di dalam teks-teks enchiriadis, chant dari liturgi menjadi pusat perhatian. Tidak mengherankan bila pada titik ini muncullah diskusi yang sistematis mengenai musik polifonis atau organum. Selain itu, muncul pembicaraan teoretis yang kemudian akan memunculkan repertoar chant yang dikenal dengan sebutan "lagu-lagu" Gregorian (Bower, 2002: 156).

Pada pertengahan abad ke-17, François Blondel (1618-1686) di dalam traktatnya mengenai arsitektur, Cours d' architecture, menyebutkan bahwa arsitektur, puisi, musik, seni berbicara, komedi, lukis, kriya dan tari dipersatukan karena hal-hal itu menjadi sumber kenikmatan bagi manusia. Penyebutan itu menjadi persiapan bagi pembagian fine arts di kemudian hari, dan juga pembedaan antara teknologi dari artes mechanicae dan ilmu pengetahuan alam. Hal ini menjadi suatu hal yang tak mengherankan bila setelah Abad Pertengahan terjadi univokalisasi yang radikal mengenai konsep art; “art(s)” akhirnya dikenal menjadi "seni" seperti yang kita kenal sekarang. Ini pula yang melatarbelakangi alasan artes liberales dipecah menjadi sejumlah bidang yang berbedabeda yaitu ilmu pengetahuan (sciences), seni (fine arts) dan teknologi. Tidak mengherankanlah bila peran Liberal Arts meredup di dalam pendidikan secara umum.

Melihat sejarah perkembangan ilmu pengetahuan, musik telah salah dipahami sebagai bagian dari matematika, walaupun demikian kesalahan itu bukannya tidak berdasar, oleh sebab itu kita harus memahaminya secara bagian per bagian.

Pertama, sudah ada keyakinan di dalam pemikiran Yunani Kuno bahwa planet-planet berbunyi. Prier menyebutkannya Saturnus bernada $d^{1}$, Yupiter bernada $c^{1}$, Mars bernada b, matahari bernada a, Venus bernada g, Merkurius bernada $\mathrm{f}$ dan bulan bernada e (Karl, 1991: 30). Gagasan itu bisa disimpulkan bahwa musik adalah multitudo yaitu sesuatu yang direpresentasikan oleh bilangan dan sekaligus magnitudo yaitu sesuatu yang direpresentasikan oleh bentuk yang berbunyi. Artinya, musik pada masa Yunani Kuno adalah memang bagian dari matematika.

Kedua, gagasan Yunani Kuno tentang musik tersebut memang kemudian masuk dalam pemikiran Abad Pertengahan; dengan demikian gagasan musik adalah matematika dilanjutkan kembali. Akan tetapi, apa yang tadinya dipikirkan secara demikian, agaknya mulai berusaha untuk dikoreksi. Sudah timbul pemikiran bahwa yang dipandang secara demikian di Yunani Kuno sesungguhnya adalah tindakan berpikir secara analogis. Musik adalah tidak sama dengan matematika, tetapi memiliki kesamaan-kesamaan tertentu yang sifatnya matematis. Oleh sebab itu melalui musik kita bisa memahami alam semesta, tetapi musik adalah bukan penjelasan mengenai alam semesta itu sendiri.

Ketiga, Boethius menjadi orang yang membuat transisi antara musik yang matematis dan musik "proper", itulah sebabnya ia membuat adanya tiga jenis musik. Penulis melihat bahwa ini adalah sebuah usaha untuk mulai perlahan-lahan tapi pasti membentuk studi musik seperti yang dikenal. Hal ini terlihat dari progresi musica dari Boethius menuju Aurelian dan Regino: Musica in instrumentis constituta - cantor - Musica naturalis/artificialis. Terakhir, masuklah pada gagasan teori musik yang kemudian menjadi gagasan yang berkembang terus di kemudian hari: Musica enchiriadis. 
Paparan tiga langkah perkembangan musica di atas menunjukkan perjalanan gagasan musik, dari yang "bukan musik an sich" menjadi "musik proper". Perjalanan itu memperlihatkan perpecahan-perpecahan yang akhirnya membentuk "pemurnian" secara tertentu. Tujuan penulis di sini adalah ingin menunjukkan bahwa "perjalanan" semacam ini juga terjadi pada masa sekarang.

Perkembangan musik berisi perpecahanperpecahan yang dari masa Yunani Kuno hingga Abad Pertengahan - mengarah pada semacam pemurnian, tetapi gagasan perpecahan itu adalah sesuatu yang melekat di dalam musik. Cara pandang seperti ini mengatakan bahwa disrupsi di dalam musik tidak hanya terjadi pada masa sekarang dimana musik menjadi semakin tercampur-aduk di dalam teori dan praktek. Disrupsi sudah terjadi sejak perkembangan di dalam sejarah musik yang dalam sejarah kebudayaan disebut sebagai "era Modern”, yaitu periode musik Barok-KlasikRomantik-Abad XX-Abad XXI.

Jikalau orang mengatakan bahwa era disrupsi adalah era masa kini, tidak demikian halnya dengan musik; dalam musik disrupsi adalah suatu keniscayaan di dalam sejarahnya. Harus diakui ada perbedaan disrupsi masa kini dengan masa sebelumnya; perbedaannya terletak pada kecepatannya semata dan itu semua didorong oleh kemajuan teknologi. Tetapi jika kita mengatakan mengapa musik sekarang sedemikian sulit dipahami, hal ini disebabkan karena di dalam dirinya sudah mengandung keinginan untuk melakukan disrupsi diri!

\section{Penutup}

Disrupsi adalah sebuah kata yang menggetarkan dan menggentarkan di dalam kehidupan sekarang. Ia adalah sebuah keadaan yang dipandang khaos, yang sebelumnya tidak ada presedennya. Keadaan disebut disrupsi disebabkan karena teknologi merasuki segala lapisan bidang kehidupan; keadaan ini tidak pernah dipersiapkan karena perkembangan teknologi itu sendiri tidak pernah bisa ditebak sampai di mana kemajuannya.

Keadaan khaos tidak menimbulkan masalah di dalam musik, hal ini disebabkan karena disrupsi di dalam musik adalah suatu keniscayaan; sebab sudah dari sejarahnya disrupsi melekat di dalam musik. Disrupsi seolah-olah merupakan "barang baru" juga di dalam seni; kesalahpahaman ini disebabkan karena ketidaktahuan situasi awal musik ketika ia dipandang sebagai bagian dari studi LiberalArts di Abad Pertengahan.

Dengan meminjam kerangka pikir dari ilmu teknik, disrupsi di dalam musik dapat terpetakan, di sini disrupsi malah bisa dibentuk metodologinya. Pemahaman mengenai metodologi disrupsi di dalam musik memperlihatkan bahwa perkembangan di dalam musik bukan tidak memiliki pola yang tertentu; pola-pola itu bisa terpetakan dengan tiga aspek, yaitu: aspek horizontal, aspek vertikal, dan aspek aksiologis.

Aspek horizontal berbicara mengenai disrupsi yang membuat genre musik bercampur dengan genre dari seni-seni lain. Aspek vertikal berbicara mengenai disrupsi yang membuat terjadinya percampuran subgenre di dalam genre musik. Aspek aksiologis menunjukkan bagaimana permasalahan musik tidak lagi berhubungan dengan musik yang teknis maupun teoretis; aspek ini menunjukkan bagaimana musik terhubung dengan permasalahan yang sifatnya non-musik dan bahkan tidak ada hubungannya sama sekali dengan seni. Aspek aksiologis yang membuat disrupsi di dalam bidangbidang non-musik dipandang sebagai keharusan sebuah bidang untuk bersifat interdisipliner.

Disrupsi adalah suatu keniscayaan di dalam musik. Ia adalah sesuatu yang sudah inheren di dalam musik, dan ia merupakan sebuah Leitmotiv di dalam musik. Jikalau pun ada permasalahan disrupsi yang mengganggu di dalam musik, hal itu dalam hubungannya dengan pendidikan musik. Hal ini terlihat dari metodologi di dalam disrupsi musik. Di dalam ketiga aspek itu terdapat banyak permasalahan yang bahkan satu sama lain lebih sering tidak saling berhubungan. Bagaimana mempelajari musik secara purna dengan keadaan seperti itu? Apa yang harus dipelajari sebagai materi dasar di dalam studi musik? Bagaimana mempersiapkan siswa di dalam disrupsi yang akan dihadapinya? dan seterusnya. Inilah permasalahan yang tidak tercakup di dalam tulisan ini, tetapi tulisan ini menguaknya. 


\section{Kepustakaan}

Bower, C. M. (2002). The Transmission of Ancient Music Theory into the Middle Ages. In T. Christensen (Ed.), The Cambridge History of Western Music Theory (pp. 136-167). Cambridge: Cambridge University Press.

Cooper, B. L. (1991). Popular Music Perspectives: Ideas, themes, and patterns in contemporary lyrics. Ohio: Popular Press.

Dru, J.-M. (2007). How Disruption Brought Order: the story of a winning strategy in the world of advertising. New York: St. Martin's Press.

Hicks, A. J. (2017). Composing the World: Harmony in the Medieval Platonic Cosmos. New York: Oxford University Press.

Hsu, H. (2017). Identity and Intention The New Yorker. The New Yorker, 93(28), 69.

Hughes, D., Evans, M., Morrow, G., \& Keith, S. (2016). The New Music Industries: Disruption and Discovery. United States: Palgrave Macmillan.

Irawati, E. (2017). Transmisi Kelentangan dalam Masyarakat Dayak Benuaq. Resital Jurnal Seni Pertunjukan, 17(1), 1-18.

Johnson, R., \& Stahl, W.H. (1971). The Quadrivium of Martianus Capella: Latin traditions in the mathematical sciences, 50 BC-AD 1250 (Vol. 1). New York: Columbia University Press.

Karl, E. P. S. (1991). Sejarah Musik Jilid 1. Pusat Musik Liturgi. Jogjakarta: Pusat Musik Liturgy.

Laksono, K. L., Anggreni Purba, S., \& Dona Hapsari, P. (2015). Musik Hip-Hop sebagai
Bentuk Hybrid Culture dalam Tinjauan Estetika. Resital Jurnal Seni Pertunjukan, 16(2), 75-83.

Little, M., \& Jenne, N. (2001). Dance and the Music of JS Bach. Tucson: Indiana University Press.

Machin, D. (2010). Analysing popular music: Image, sound and text. Sweden: Sage Publications.

Marshall, S. (1994). Jean, Jazz Dance-The Story of American Vernacular Dance. New York: Da Capo Press.

Middleton, R. (2000). Reading Pop: Approaches to Textual Analysis in Popular Music: Approaches to Textual Analysis in Popular Music. USA: Oxford University Press.

North, A. C., \& Davidson, J. W. (2013). Musical Taste, Employment, Education, and Global Region. Scandinavian Journal of Psychology, 54(5), 432-441.

Prasetyo, H. (2017). Industri 4.0: Telaah Klasifikasi Aspek dan Arah Perkembangan Riset.J@Ti Undip: Jurnal Teknik Industri, 1(1), 17-26.

Stamatellos, G. (2012). Introduction to Presocratics: a thematic approach to early Greek philosophy with key readings. USA: John Wiley \& Sons.

Suwardana, H. (2017). Revolusi Industri 4.0 Berbasis Revolusi Mental. Jurnal Ilmiah Teknik Dan Manajemen Industri, 1(2), 102110. https://doi.org/http://ojs.unik-kediri. ac.id/index.php/jatiunik/article/view/117/0

Vernallis, C. (2004). Experiencing music video: aesthetics and cultural context. USA: Columbia University Press. 